\title{
Reassessment of the Resources of a Deep Aquifer System under Physical and Chemical Constraints: The Maastrichtian Aquifer
}

\author{
Cheikh Hamidou Kane ${ }^{1}$, Moustapha Diene ${ }^{2}$, Meissa Fall ${ }^{1}$, Baba Sarr ${ }^{3}$, Alassane Thiam ${ }^{4}$ \\ ${ }^{1}$ Laboratoire de Mécanique et Modélisation-UFR Sciences de l’Ingénieur, University of Thiès, Thiès, Senegal \\ ${ }^{2}$ Département de Géologie, FST-UCAD, Cheikh Anta Diop University, Dakar, Senegal \\ ${ }^{3}$ Laboratoire de Géologie, IFAN, Cheikh Anta Diop University, Dakar, Senegal \\ ${ }^{4}$ ISRA, Bambey, Senegal \\ Email: cheikh.kane@univ-thies.sn
}

Received December 19, 2011; revised January 19, 2012; accepted February 16, 2012

\begin{abstract}
The deep and confined Maastrichtian aquifer contains considerable groundwater resources. It stretches over nearly 200,000 $\mathrm{km}^{2}$, from the northern part of Mauritania to the South of Guinea Bissau where it becomes shallow. The reservoir is composed mainly of coarse sands and sandstone interbedded with some clay units. The aquifer provides $40 \%$ of the total drinking water extracted from the different aquifers and nearly 800 wells equally distributed operate only in the top $50 \mathrm{~m}$ of the aquifer. Despite the importance of these resources for providing water in the rural and urban areas, the aquifer characteristics are not well defined. The present paper aims to define first the physical and chemical characteristics of the Maastrichtian aquifer. The reserve of the aquifer initially estimated at 350 billion $\mathrm{m}^{3}$, is reassessed using new data providing from cross sections realized as part of our research, through the Water Sectorial Project of the Ministry of Hydraulics. Data from oil wells and geophysical logging are used to investigate the geometry of the aquifer and the position of the fresh/salty water interface. The highest thickness of the aquifer is between 200 to $400 \mathrm{~m}$ and salty water is present below the fresh groundwater in the west side of the aquifer. In the Eastern side, potable water lies directly above the basement. The thickness of the aquifer increases from the west to the center, and then decreases towards the shallow basement rock in the South East. The average thickness is $250 \mathrm{~m}$. Chemical data coming from pumping wells indicate high chloride (250 - $1600 \mathrm{mg} / \mathrm{l})$ and fluoride content $(1-5.5 \mathrm{mg} / \mathrm{l})$. Therefore, the reassessment has to take into account the chemical aspect of the water.
\end{abstract}

Keywords: Maastrichtian; Groundwater; Deep Aquifer; Senegalese-Mauritanian Sedimentary Basin; Characteristic; Pollution; Reassessment

\section{Introduction}

In Senegal, groundwater is the major source of drinking water supply; it ensures $80 \%$ of it. The Maastrichtian deep aquifer, which occupies about four fifths of the territory of Senegal (e.g. 155,000 $\mathrm{km}^{2}$ ), is the most important one. More than thousand boreholes are taping these resources, located nearly at $250 \mathrm{~m}$ deep. Maastrichtian groundwater has a regional scale, since it occurs in a large part of the sedimentary basin between Senegal and Mauritania and is present from the South of Guinea Bissau to the north of Mauritania, through the Gambia.

Most of the information available on the aquifer derives from boreholes mainly located in Senegal. That is why, only top layers are well known, since the production wells are mainly taping aquifer top levels; discharge rates are generally high, they may reach 150 to $200 \mathrm{~m}^{3} / \mathrm{h}$.

The aim of this paper is first, to characterize the fresh groundwater boundary based on geological cross sections obtained from data collected at the borehole national database in Senegal and secondly, to re-assess the aquifer storage. One also proposes to explain physical and chemical groundwater features, which are major constraints for quantitative and qualitative assessment of the resources.

\section{Geological and Hydrogeological Context}

The Senegalese-Mauritanian sedimentary basin (Figure 1) consists mainly of secondary and tertiary formations. They are lying above a substratum made up with crystalline rocks of Precambrian and primary age, which outcrops in the South-East and North-East of the basin. Lithostratigraphy of geological formations, starting from Jurassic, is well known, mainly thanks to oil exploration boreholes. 


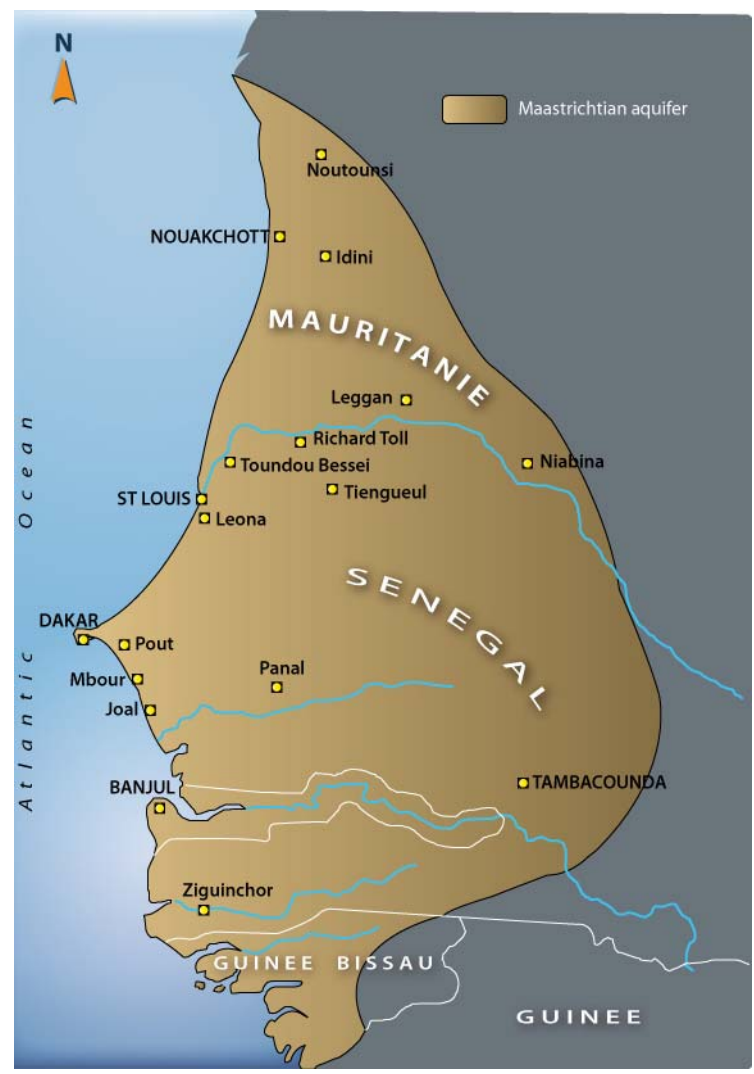

Figure 1. Maastrichtian deep aquifer of the basin between Senegal and Mauritania [1] modified.

The Maastrichtian layers containing the groundwater are outcropping at the Dias horst as clayey/calcareous sandstones or sandy clay. In Senegal, in the central and eastern part of the basin, sands with interbedded clay dominate. Layers of thin lignite can be observed at the top of the stage. In the west, there are mainly sandy clay facies which become completely clayey in the west of the $17^{\circ} 30^{\prime}$ Meridian [2,3].

In Mauritania, the Maastrichtian is represented by azoic clayey sand formation [4]. However, the sandy levels are becoming more important as you get nearer the eastern edge of the basin where their thickness is thin $(10-50 \mathrm{~m})$. In the western part there are fine to coarse sands alternating with pyritic and sometimes lignite clays. In this country the Maastrichtian groundwater is of very limited interest.

In Guinea Bissau however, the Maastrichtian aquifer is relevant for domestic water supply. Groundwater is contained in fine to medium sands, with presence of pyrite, glauconite and lignite, similarly to Senegal case [2]. The aquifer layers outcrops in the east and west part of the country; it becomes deeper and confined in the country center.

The groundwater does not solely occurring in Maastrichtian geological formation. Indeed, lower aquifer layers are Campanian formations, particularly in Dias horst area. Similarly, in the eastern edge of the basin, the upper aquifer layers may be Paleocene ones [1]. The aquifer is confined in the whole territory of Senegal, except in the Dias horst where it is unconfined and maintaining lateral hydraulic contact with Paleocene karstic aquifer. Its confining bed is made of marl or clay belonging to Paleocene. It is overlaid by a set of geological formations encountering several aquifers, with a more or less limited extension. These minor aquifers are observed in the $\mathrm{Pa}-$ leocene (karstic limestone around Mbour), in the Eocene (Lutetian limestone near Louga and Kébémer), in the Oligo-Miocene (clayey sands in Kaffrine area, in the central-eastern Basin), in the Quaternary (coastal sands of the north-west and alluvium of major rivers).

\subsection{Physical and Chemical Groundwater Features}

Studies carried out on the Maastrichtian groundwater [3, $5,6]$ revealed a relative balance of the water chemistry in the last 30 years. No significant changes were noted; the total mineralization is still stable. Measurements made at different times provide an overview of the groundwater chemical composition (Table 1). High rates of chloride

Table 1. Some examples of chemical compositions (mg/l) from the Maastrichtian groundwater between 1967 and 1994 [3,6] modified.

\begin{tabular}{|c|c|c|c|c|c|c|c|c|c|c|c|c|}
\hline Place & Year & $\mathrm{T}\left({ }^{\circ} \mathrm{C}\right)$ & $\mathrm{pH}$ & $\mathrm{Ca}^{2+}$ & $\mathrm{Mg}^{2+}$ & $\mathrm{Na}^{+}$ & $\mathrm{K}^{+}$ & $\mathrm{Cl}^{-}$ & $\mathrm{SO}_{4}^{2-}$ & $\mathrm{HCO}_{3}^{-}$ & $\mathrm{F}^{-}$ & TDS \\
\hline \multirow[t]{2}{*}{ DIOURBEL } & 1967 & - & - & 8.2 & 2.42 & 484.1 & 16.6 & 475.7 & 43.2 & 466.7 & 2.1 & 1499.1 \\
\hline & 1984 & $39^{\circ} 1^{\prime}$ & 7.85 & 4.1 & 2.7 & 480 & 8.0 & 500 & 43.0 & 492.9 & 4 & 1534.7 \\
\hline \multirow[t]{3}{*}{ KAFFRINE } & 1970 & $37^{\circ}$ & 7.9 & 13.6 & 4.6 & 274 & 11.0 & 224 & 45.1 & 360 & 0.8 & 932.3 \\
\hline & 1984 & $38^{\circ} 8^{\prime}$ & 8.1 & 5.6 & 4.9 & 266 & 9.6 & 220 & 48.0 & 337.9 & 1.1 & 893.1 \\
\hline & 1994 & - & - & 16.0 & 2.6 & 173.7 & 10.0 & 233.0 & 65.0 & 316 & - & - \\
\hline \multirow{2}{*}{ KAOLACK } & 1984 & $37^{\circ} 9^{\prime}$ & 7.93 & 4.0 & 3.3 & 440 & 20 & 330 & 73.5 & 416.03 & 2.78 & 1289.6 \\
\hline & 1994 & - & - & 4.0 & 3.3 & 393.3 & 13.7 & 370.0 & 62.0 & 390 & - & - \\
\hline \multirow[t]{3}{*}{ LINGUERE } & 1970 & - & 7.5 & 54.1 & 21.4 & 144 & 17.4 & 42.5 & 256.5 & 253.2 & 0.4 & 789.1 \\
\hline & 1984 & $39^{\circ} 5^{\prime}$ & 7.02 & 48.6 & 22.0 & 140 & 8 & 33 & 290 & 245.2 & 0.55 & 841.8 \\
\hline & 1994 & - & - & 52.9 & 21.2 & 158 & 17.3 & 70.0 & 328.0 & 209 & 0.7 & - \\
\hline
\end{tabular}


are being noticed, which provides evidence of the presence of brackish water. The average $\mathrm{pH}$ values are ranging from 5.8 at the eastern and western boundaries and 7.9 to 8.6 in the centre and the North [3]. The temperature varies between $36^{\circ} \mathrm{C}$ and $45^{\circ} \mathrm{C}$, its distribution roughly follows the confining bed morphology [6].

Two major phenomena characterize the Maastrichtian groundwater chemistry. The total mineralization varies between 200 and 12,000 mg/l [6], when one looks over this feature, it showcases three main areas:

- East of the $15^{\circ} 30$ longitude where mineralization is between 200 and 700 mg/l (Figure 2);

- At Dias horst surroundings on a narrow strip where mineralization is less than $1000 \mathrm{mg} / \mathrm{l}$;

- A central area, located in the west of longitude $15^{\circ} 30^{\prime}$ where groundwater has high chloride content ranging from 250 to $1600 \mathrm{mg} / \mathrm{l}$, with a sodium chloride facies [7].

The second feature is the naturally occurring fluoride, which is widespread phenomenon in the Senegalese basin' aquifer systems; it also affects large part of the Maastrichtian aquifer. Accurate mapping of fluoride contents was developed by Travi [6]. It shows a regular evolution (Figure 3), with values increasing from recharge areas (Dias horst and eastern sedimentary boundaries) to the Centre-West. The location of high levels of fluoride is associated with the presence of phosphate deposits, one of the minerals of which, precisely the apatite-fluoride, is the main source of fluoride content in the Maastrichtian groundwater [6]. High concentrations (1 - $5.5 \mathrm{mg} / \mathrm{l})$ are primarily occurring between the Dias horst' eastern boundary and the $15^{\circ} 30^{\prime}$ parallel, which corresponds to the zone of high mineralization, described earlier.

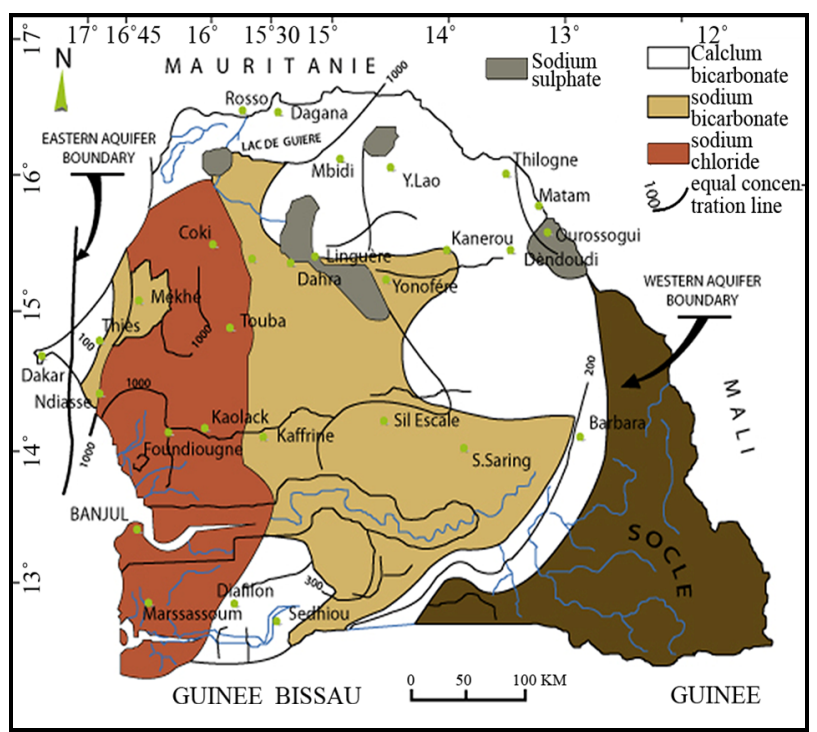

Figure 2. TDS and chemical facies of the deep Maastrichtian groundwater [6] modified.

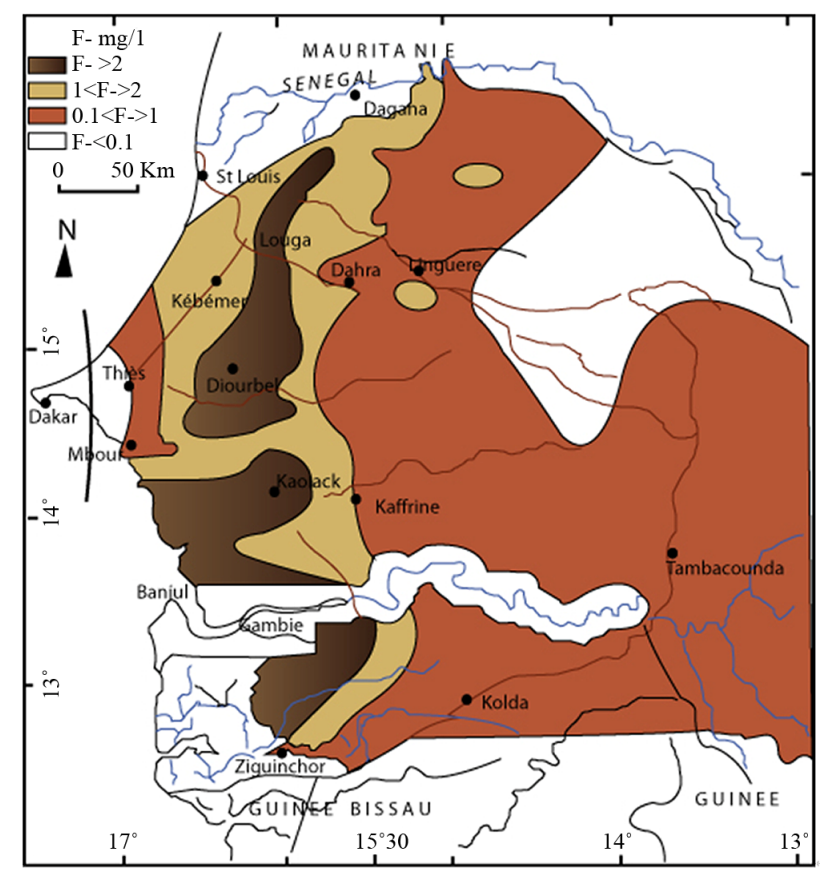

Figure 3. Map of fluoride contents of the deep Maastrichtian groundwater [6] modified.

\subsection{The Aquifer Geometry}

Most of the available data on the deep Maastrichtian aquifer concerns the upper layers (50 - $100 \mathrm{~m}$ ). They are provided by boreholes drilled to meet water demand for domestic, industrial or touristic purposes. Such a situation has always been an obstacle for determining the vertical aquifer boundaries, notably the extent of the fresh groundwater.

In this paper data from deep oil boreholes drilled beyond the Maastrichtian geological formations were used, as well. They are related, either to logs that give more or less detailed information on the lithostratigraphy of the thick sedimentary basin (the deepest borehole has reached $5395 \mathrm{~m}$ on the southern coast), or to resistivity and spontaneous polarization (PS) profiles. These test holes are essentially located in the western basin especially in Senegalese territory, this explains partly knowledge deficit on the aquifer that is observed in the East, Centre, and in the neighboring countries. However they have contributed to the exploration of aquifer bottom layers. Complementary data derived from geophysical surveys made near the eastern and southeast of the sedimentary basin boundary [8] have helped to fill in the information gap in this area.

Thus, the geological cross sections in this paper (Figure 4) were based on data mentioned above, as well as those provided by Dieng [9] and Le Priol [10] and Bellion [4] on the sedimentary basin' structural geology. The following observations have been made from their interpretation: 


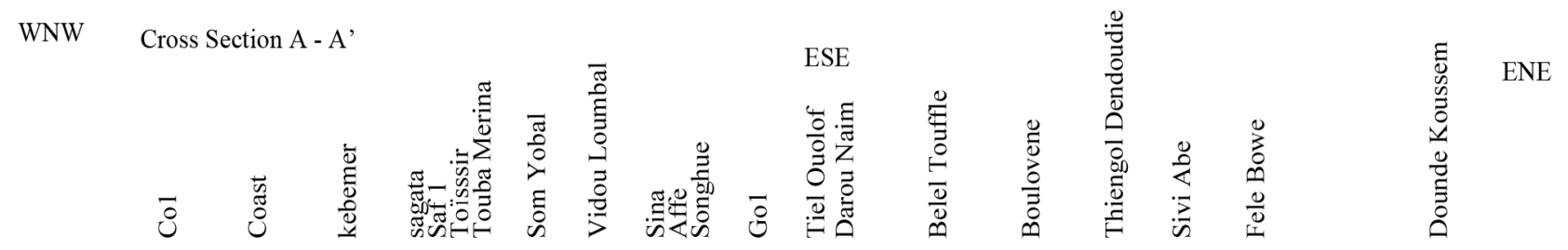

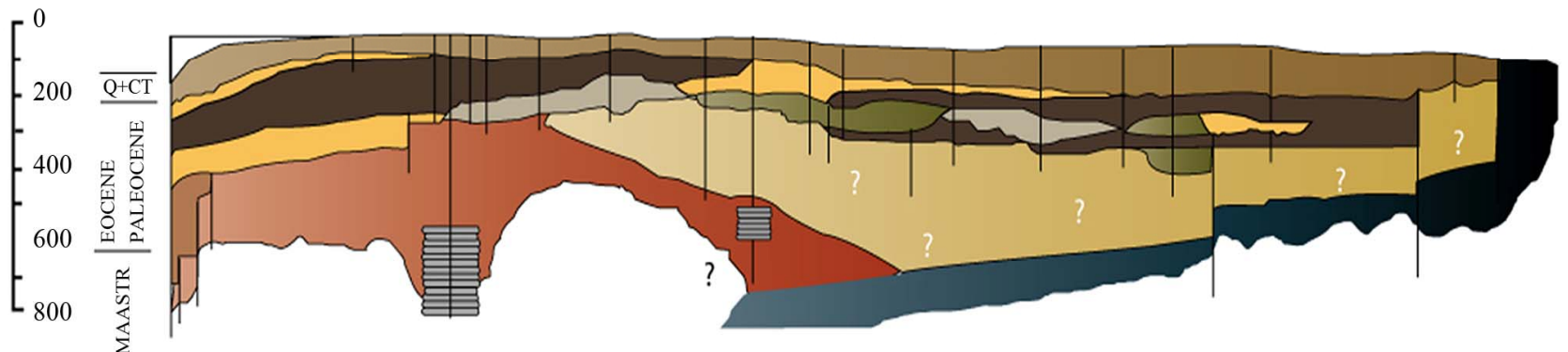

(a)
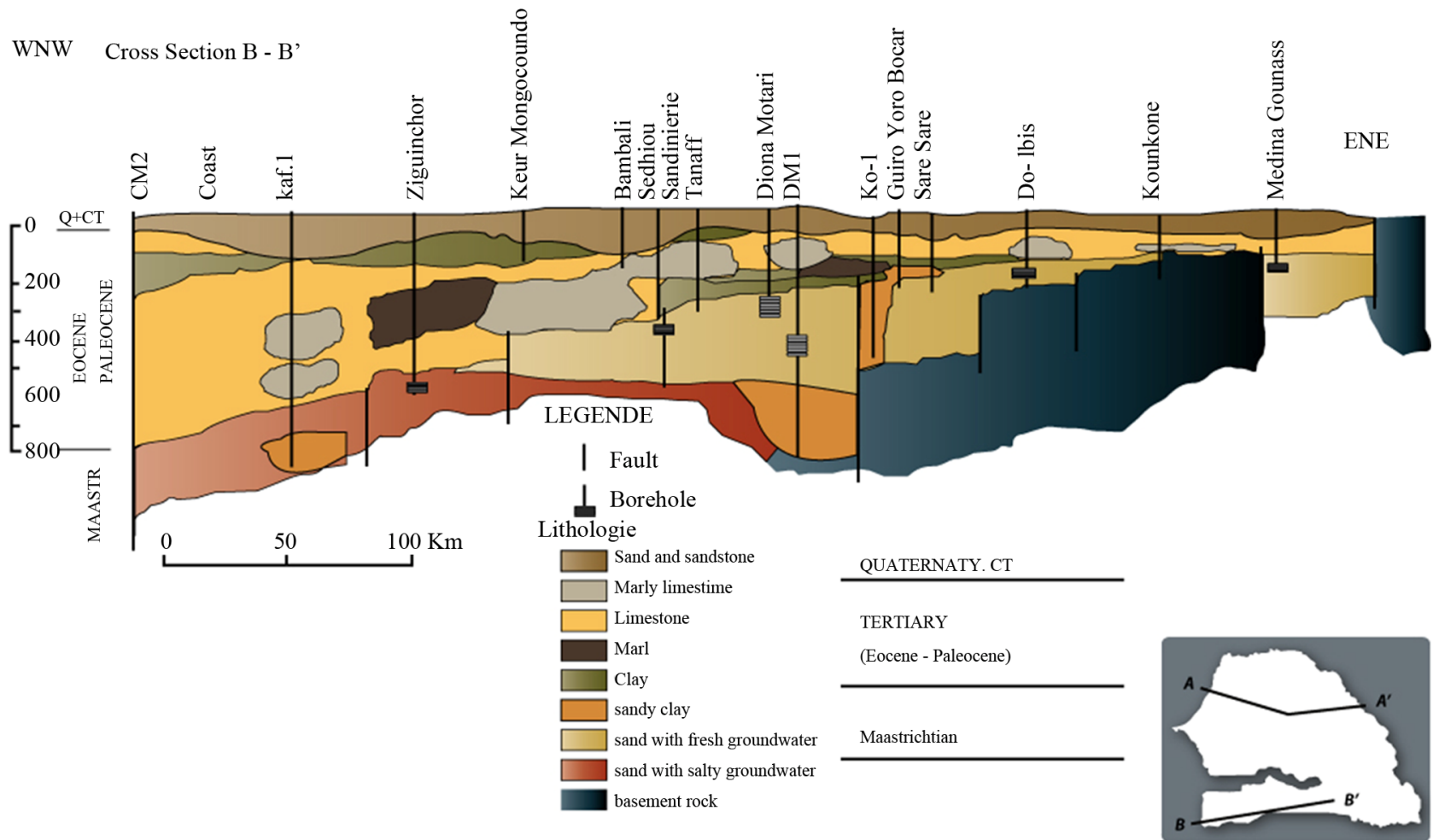

(b)

Figure 4. (a) Geological cross section of the northern part of Senegalese sedimentary basin; (b) Geological cross section of the southern part of Senegalese sedimentary basin.

- The aquifer confining bed is affected by sets of faults that led to a subsidence of top layers, evolving from east to west (excepted for Dias horst);

- Fresh groundwater overlies brackish ones at the west and partly at the center, while at the east it is underlain by crystalline basement.

The isobathic map of the confining bed (Figure 5) also shows this general trend with increasing aquifer' top layers depth, from east to west, excepted for Dias horst) and Tambacounda surroundings.

The isopach line map gives a general picture of fresh groundwater thickness (Figure 6). Its value is relatively high at the basin center where it can reach $400 \mathrm{~m}$ in some places, whereas it's decreasing to the west and east.

\section{Fresh Groundwater Storage Assessment}

To assess Maastrichtian groundwater storage, one needs 
to overcome two major constraints.

\subsection{Chemical Constraints}

High mineralization and high fluoride rate are major constraints that are harmful to the groundwater quality. Drinking water is considered good if ion concentration is below $1000 \mathrm{mg} / \mathrm{l}$, and according to international standards, fluoride concentration should be less than $1.5 \mathrm{mg} / \mathrm{l}$. To this line groundwater stored between the $15^{\circ} 30^{\prime}$ and $16^{\circ} 45^{\prime}$ parallel cannot be considered as suitable with respect to drinking purposes. Therefore, the quality aspect has to be taken into account in the assessment of groundwater resources.

Thus, the areas suitable for water supply for populations are located, either in the east of $15^{\circ} 30^{\prime}$ parallel, or, in the west of latitude $16^{\circ} 45^{\prime}$ (Figure 7).

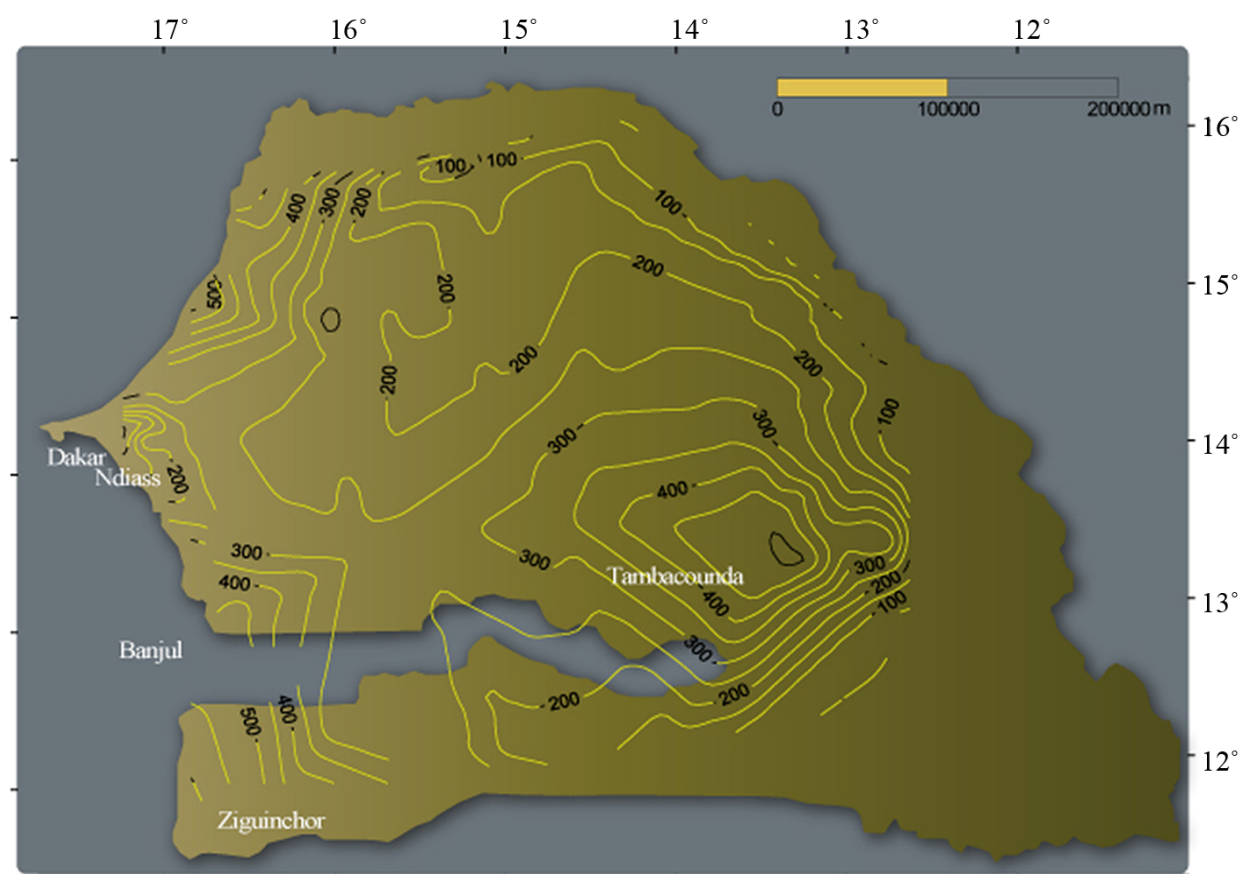

Figure 5. Isobathic map of aquifer confining bed.

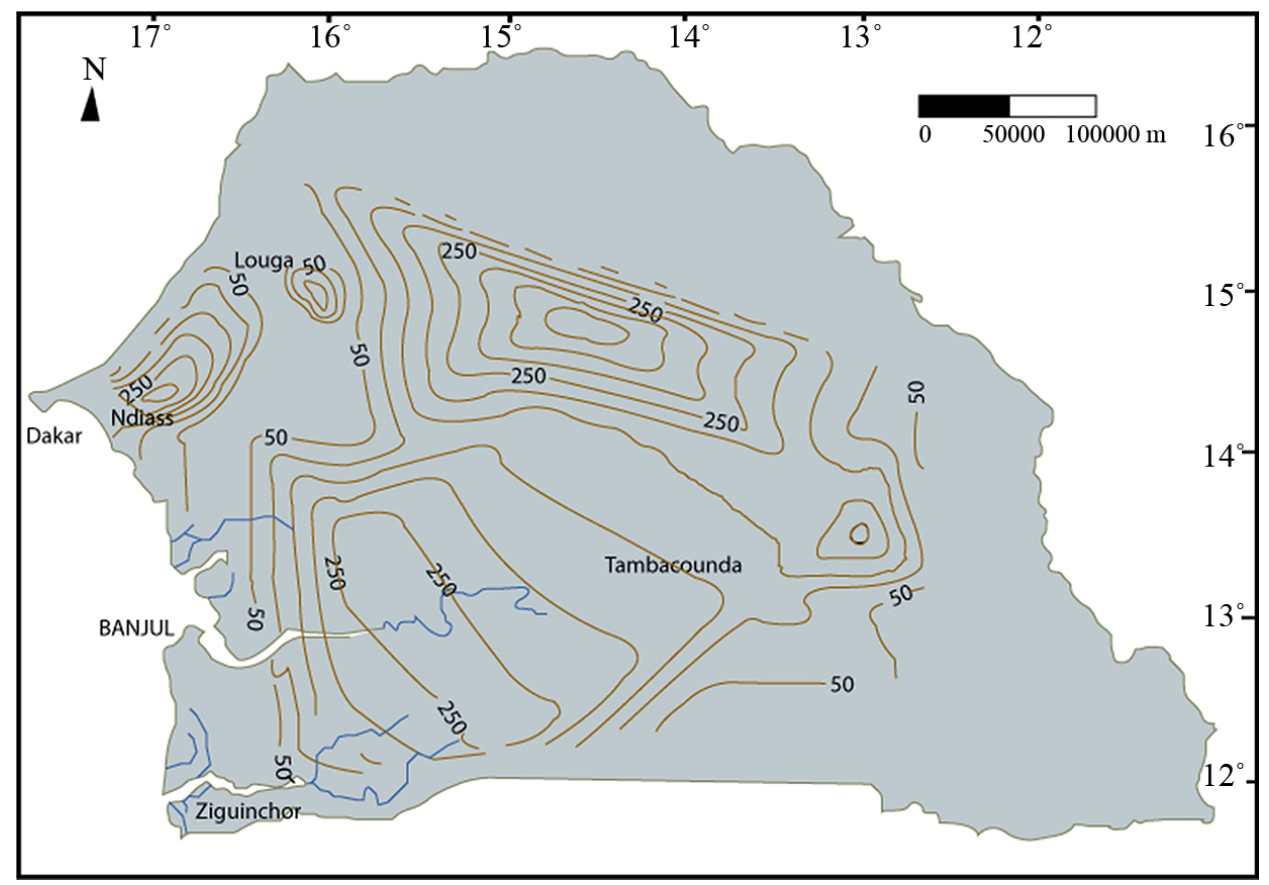

Figure 6. Isopach line map of fresh groundwater contained by the deep Maastrichtian aquifer. 


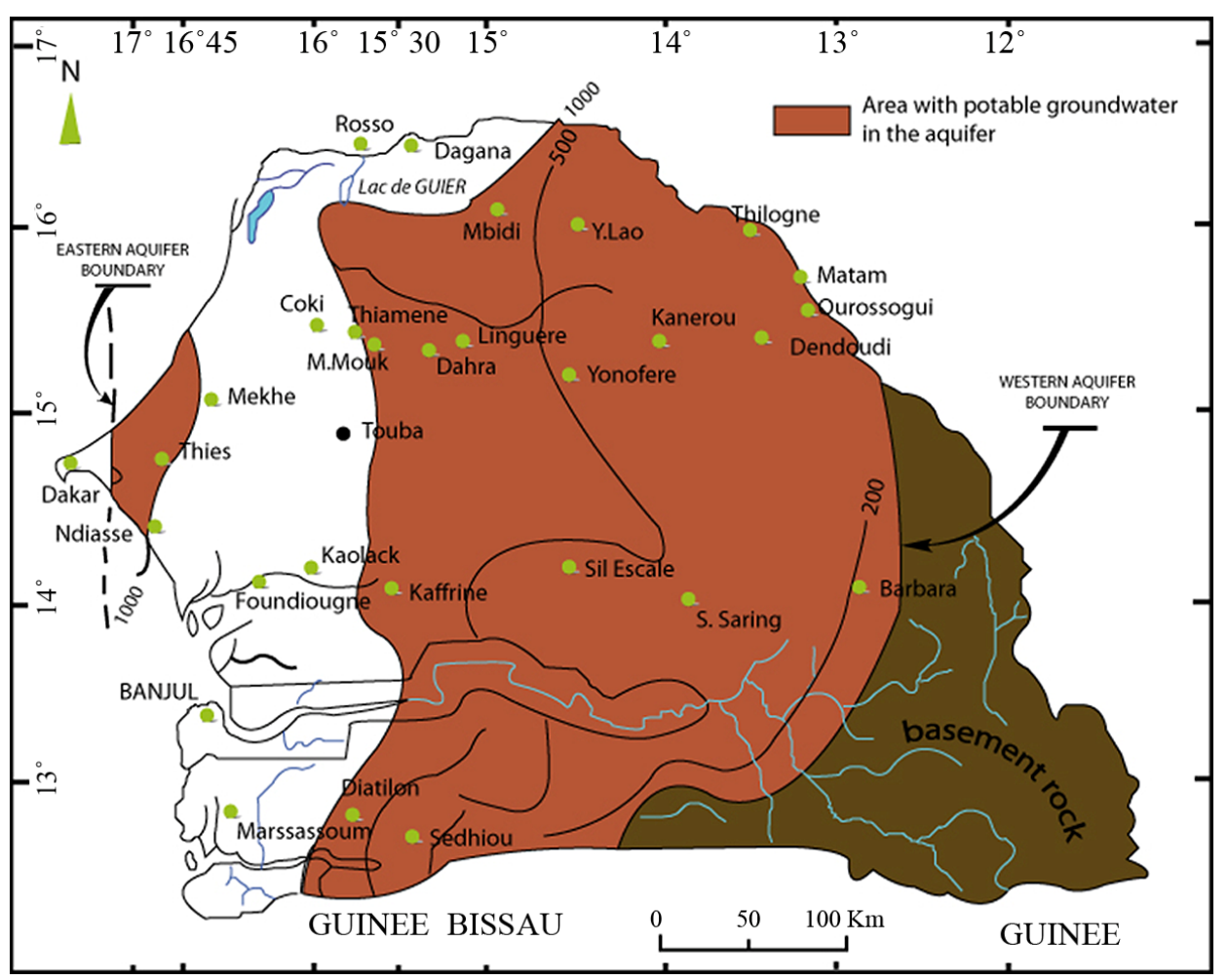

Figure 7. Fresh groundwater' location map of the deep maastrichtian aquifer.

\subsection{Physical Constraints}

Physical constraints are rather related to non-representtative data on groundwater hydraulic parameters. Indeed pumping tests are performed on wells that generally tap the first 50 meters of the aquifer, which is very small compared to the mean aquifer thickness. In addition to that, the tests are often of relatively short duration. Therefore, the computed hydraulic parameters are fairly representative of aquifer top layer. After corrections and extrapolations, Doumouya [2] advocates using transmissivity values between $4 \times 10^{-2}$ and $10^{-3} \mathrm{~m}^{2} / \mathrm{s}$.

Moreover, the storage coefficient is more difficult to define. In fact, pumping tests are usually carried out without observation well to monitor drawdown, which is an obstacle to its computation. The available values are mostly from Dias horst, where they vary between $8 \times$ $10^{-4}$ and $1 \times 5.10^{-4}[9,11]$. In the rest of the basin, there are only few data on wells located in Centre (Kaolack) and south (Ziguinchor). They range nearly around $\sim 2.8 \times$ $10^{-4}-2 \times 5.10^{-4}$. These latter indicate that there is little variation for this parameter within the basin, as Dieng noted [9]. For the purpose of this study, we will assume 2 $\times 10^{-4}$, which seems representative of the center of the basin, where we observe highest aquifer layers thickness.

\subsection{Groundwater Storage Assessment}

The groundwater storage evaluation of the Maastrichtian aquifer will take into account the groundwater portion, which chemical characteristics are compatible with drinking water standards. So we shall consider, first the strip located approximately between the $16^{\circ} 45^{\prime}$ and $17^{\circ}$ parallel and secondly, the area located east of the $15^{\circ} 30^{\prime}$ parallel (Figure 7). These two parts together cover an area of $123,400 \mathrm{~km}^{2}$, out of a total aquifer area of 176,650 $\mathrm{km}^{2}$, or $70 \%$.

The average thickness obtained from geological cross sections, which are fairly representative for the center and the southern boundary of the basin, provides an approximate value of $270 \mathrm{~m}$. Thus, for a storage coefficient of about $2.10^{-4}$, the total fresh groundwater storage will be equal to 6.7 billion $\mathrm{m}^{3}$. So, we should bear in mind that, out of the 350 billion $\mathrm{m}^{3}$ often considered as the aquifer storage, about only 7 billion $\mathrm{m}^{3}$ are suitable for drinking purpose and available.

\section{Conclusion}

The deep Maastrichtian aquifer is the most important source of drinking water in Senegal and more than a thousand boreholes abstract it. However, large parts of the groundwater present physical and chemical characteristics (chloride and fluoride high rates), which do not match with drinking water features. Therefore, any groundwater assessment should take into account that aspect. Therefore, for a sustainable groundwater resources management, it is necessary to reconsider downwards ground- 
water storage, with respect quality aspects.

\section{REFERENCES}

[1] J. Forkasiewicz, "Maastrichtian Aquifer of the Sedimentary Basin of the Senegal-Mauritanien," Bulletin BRGM, Vol. 3, No. 2, 1982, pp. 185-196.

[2] I. Doumouya, "Summary of Properties of the Shell, Electrofacies and Sedimentological Facies of the Maastrichtian Aquifer: A Tool for Establishing Equivalence,” Ph.D. Thesis, Cheikh Anta Diop University, Dakar, 1988.

[3] A. Faye, "Recharge and Paleorecharge Deep Aquifers of the Basin of Senegal. Contribution of Stable and Radioactive Isotopes in the Environment, and Paleoclimatic Implications Palaeohydrological,” Ph.D. Thesis, Cheikh Anta Diop University, Dakar, 1994.

[4] J.-C. Bellion, "Post-Paleozoic Geodynamic History of West Africa According to the Study of Some Sedimentary Basins (Senegal, Taoudenni Iullemmenden, Chad),” Ph.D. Thesis, University of Avignon, Avignon, 1987.

[5] X. Poul, Y. Vuillaume and M. Audibert, “Deep Aquifer of Senegal (Water Maestrichtian). Interpretation of Peri- odic Observations from 1967 to 1970 . Interpretations of Isotopic Analysis. Hydraulic Operation of the System,” Report BRGM RME 71-035, 1971.

[6] Y. Travi, "Hydrogeochemistry and Hydrogeology of the Aquifers Fluorinated Basin of Senegal. Origin and Transport Conditions of Fluoride in Groundwater,” Ph.D. Thesis, University of Paris-Sud, Orsay, 1988.

[7] SGPRE-Cowi/Polyconsult, "Chemistry Survey,” Working Paper No. 6, PSE, 1999.

[8] DGRH, “Campaign for Recognition by Geophysical Electrical. 166 Electrical Soundings, Deltaic Regions and Eastern Edge,” Report, CPGF Horizon, 1990.

[9] B. Dieng, "Palaeohydrogeological Hydrology and Quantitative Sedimentary Basin of Senegal. Attempt to Explain the Piezometric Anomalies,” Ph.D. Thesis, Ecole Nationmale des Mines de Paris, Paris, 1987,

[10] J. Le Priol and B. Dieng, "Hydrogeological Synthesis of Senegal (1984-1985). Geological Structural Photo-Interpretation. Geometry and Boundaries of Groundwater Aquifers,” Summary Report DEH, Ministry of Water, 1985.

[11] Arlab, "Water Supply of ICS. Complementary Study of the Maastrichtian,” Final Report No. 183/83, 1983. 